\title{
COVID-19, Distance Learning and Educational Inequality in Rural Ethiopia
}

\author{
Degwale Gebeyehu Belay ${ }^{1 *}$
}

\begin{abstract}
${ }^{1}$ Department of Governance and Development Studies, Bahir Dar University, ETHIOPIA
\end{abstract}
*Corresponding Author: deg.geb@gmail.com

Citation: Belay, D. G. (2020). COVID-19, Distance Learning and Educational Inequality in Rural Ethiopia. Pedagogical Research, 5(4), em0082. https://doi.org/10.29333/pr/9133

\begin{tabular}{|c|c|}
\hline ARTICLE INFO & ABSTRACT \\
\hline Received: 10 Jun. 2020 & ue to COVID-19 outbreak, schools are closed in many countries of the world. China is the first to develor \\
\hline Accepted: 18 Aug. 2020 & $\begin{array}{l}\text { distance learning program of 'Schools Out, But Classes On' not to disrupt learning. Ethiopia has closed schools on } \\
16 \text { March } 2020 \text { after it has confirmed the first coronavirus on } 13 \text { March } 2020 \text {. To avoid the disruption of learning } \\
\text { the Ethiopian Ministry of Education has tried to develop strategies to resume classes at home. Accordingly, radio } \\
\text { and TV education programs are designed for primary education, TV program for secondary education, and online } \\
\text { teaching for higher education. This article aimed at exploring the educational inequality of rural students of } \\
\text { Ethiopia using situational analysis. The findings unveil the multiple inequalities of rural students that make them } \\
\text { in a disadvantaged position compared to urban students. The available distance learning programs homogenises } \\
\text { students which can create educational inequality. }\end{array}$ \\
\hline
\end{tabular}

Keywords: COVID-19, distance learning, educational inequality, Ethiopia, multiple inequalities, rural students

\section{INTRODUCTION}

In late December 2019, a new virus has occurred in China in the province of Wuhan (He et al., 2020; Wise et al., 2020). The World Health Organization (WHO) used the term 2019 novel coronavirus to refer to a coronavirus that affected the lower respiratory tract of patients with pneumonia in Wuhan, China on 29 December 2019 (Adhikari et al., 2020).

The first case of COVID-19 in Ethiopia was confirmed on 13 March 2020. On 16 March 2020 the Ethiopian Prime Minister office has announced that schools, sporting events, and public gatherings shall be suspended for 15 days until further notification. However, due to increased outbreak of the virus, Ethiopia has declared a state emergency on 10 April 2020 for the next 5 months. This intensifies the closure of schools nationwide. As of 03 June 2020 (4:00 PM GMT), worldwide, 6,482,695 confirmed cases, 383,072 deaths and 3,089,101 recoveries were reported ${ }^{1}$. From the same report, it is possible to understand that, in Ethiopia, 1486 cases were confirmed, 17 deaths, and 246 recoveries.

As a result of, COVID-19, schools are closed which resulted educational disruption. Despite it is difficult to know the exact number of students who disrupted education due to COVID-19, over one billion students are affected ${ }^{2}$. This decision of temporarily closing schools was prompted by the principle that large gatherings of persons constitute a serious risk to safeguard public health during a pandemic (IESALC, 2020). As of 25 March 2020, 150 countries were reported closure of schools. In secondary schools, longer school closures could result in an increased risk of dropout for youth, particularly from lower income groups (World Bank, 2020a).

World Bank (2020b) stated the disruption of education as 'learning poverty'. The report of World Bank further indicated that with the spread of COVID-19, among many disruptions to normal life, more than 160 countries have mandated temporary school closures, leaving 1.6 billion children and youth out of school. The aim of this article is not analysing the socioeconomic consequences of educational disruption due to COVID-19; but analysing how the interventions of distance learning are exclusive that expose many students to educational inequality. The interventions taken homogenize students while the reality on the ground is different. The article also glimpse how the world is unfair in the distribution of resources which makes the declaration of 'education for all' pseudo and futile.

\footnotetext{
${ }^{1}$ Worldometer (2020). Coronavirus cases: Available at https://www.worldometers.info/coronavirus/ Accessed on 03 June 2020

${ }^{2}$ UNESCO: Coronavirus Impacts Education https://en.unesco.org/themes/education-emergencies/coronavirus-school-closures
} 
No one knows for sure how long these closures are likely to last. Initial measures taken by many governments have ranged from 15 to 30 days, but one can easily anticipate that they will be extended until the pandemic subsides (IESALC, 2020). The length of closure of schools and higher education institutions depends on the ability of the country to control the pandemic. Despite the pandemic poses a challenge globally, it adds further complexity in countries with poor growth, inequality, and poor public financing (IESALC, 2020).

The problem of COVID-19 on education is not proportionally fallen on poor and rich countries. Even, in poor countries themselves, problem is not the same in urban and rural areas. Being a citizen of poor country, living in rural area, having poor family, being a girl, and having a certain disability have different level of inequality in socioeconomic aspects. Hence, devising distance learning mechanisms; which are new models of education after the pandemic, which considers such differences of students is vital.

While schools are closed, many countries have turned to distance learning as a means of mitigating for lost time in continuing education services. Some countries are simply putting resources on their website, and making available more products, but not necessarily online classes. Infrastructure and familiarity with the tools seem to be driving successes (and challenges) of delivering learning. While countries with robust connectivity deliver distance classes effectively, others who lack it are finding it difficult to reach all students equally (World Bank, 2020a).

According to the report of World Bank (2020b), while some African countries (Kenya, Rwanda, South Africa, Senegal, Botswana, and Gambia) have reasonable connectivity and there are devices like tablets, most African countries access to mobile devices is optimized.

Using smartphones requires partnership with private provides to allow for zero charges for content downloaded from the Ministry of Education (or any agency that hosts learning resources platforms). In addition to infrastructure and connectivity, teachers' and administrators' familiarity with the tools and processes are also key factors in providing distance learning.

International organizations have paid particular attention to the issue of "Education Response in Crises and Emergencies" (Huang et al, 2020). The Chines government was the first to make deal with disrupted education since the pandemic is first found in China. The Chinese Ministry of Education has launched an initiative entitled "Disrupted Classes, Undisrupted Learning" to provide flexible online learning to hundreds of millions students from their homes (Cheng, 2020; Huang et al., 2020). This strategy was "School's Out, But Class's On" (Cheng, 2020). This is the pioneering work of online education in China and even around the world (Zhou et al., 2020).

Cheng (2020) stated that although "School's Out, But Class's On" was a measure for home study during the pandemic, its essence was still a continuation of school education. Schools are the main implementers of "School's Out, But Class's On”. This aimed at "suspending classes without stopping teaching and learning" (pp.502). Schools and departments should be organized to make sure that teachers undertake online teaching, tutoring, and homework corrections. Therefore, it is of great significance to use information technology to promote education and teaching reform, "School's Out, But Class's On" is a kind of broad-based learning, and online teaching is only one kind of format and it cannot completely replace classroom teaching (Ministry of Education of the People's Republic of China, 2020).

Different countries worldwide have introduced various solutions during the pandemic to continue the education process. Online libraries, TV broadcasts, guidelines, resources, video lectures, online channels were introduced (Basilaia \& Kvavadze, 2020). From their study in Georgia, Basilaia and Kvavadze (2020) stated that based on the first-week statistics of the online teaching process at one of the private schools; transition from the traditional to the online education systems at the school was successful. However, in Case of USA, Dorn et al. (2020) stated that despite teachers, administrators, and parents have worked hard to keep learning alive; these efforts are not likely to provide the quality of education that's delivered in the classroom.

With the help of UNCEF, the Ethiopian government developed a coasted distance learning Plan, with a focus on radio learning particularly to primary education (UNICEF, 2020a). The Ethiopian Ministry of Education has introduced radio and TV programs to primary education; TV program to secondary and online teaching to higher education (see Table 1).

Despite some initiatives are taken worldwide, the problem of distance education is different between and among students developed and developing countries. From their study in USA, Dorn et al. (2020) found out that school shutdowns disproportionately affect black and Hispanic students compared to whites. These scholars further stated that there is more drop out in these disadvantaged students. That is why this article focus on rural students who do suffered from multiple inequalities that lead to educational disadvantage compared to urban students.

Being a rural student, having a poor family, being a girl and other social dimensions intersect each other and affect students disproportionately. Therefore, the aim of this article is to unveil intersectional problems and educational inequality among urban and rural students in Ethiopia. This article focused on rural-urban divisions because the interventions of distance learning program during the pandemic, needs contextualization to be effective; unless it can create educational inequality between urban and rural students. This does not mean that there are no differences among rural and urban students themselves. The findings of this study can help governments and other national and international organizations to consider different dimensions to make distance learning effective in time of emergency like COVID-19. 
Table 1. Remote Learning Means during COVID-19

\begin{tabular}{ll}
\hline Levels of education & Means of distance learning \\
\hline Early childhood & TV and Radio \\
\hline Primary & TV, radio, and online videos \\
& Teachers can communicate their students via SMS and social media \\
\hline Secondary & Predominantly online but can be supplemented sometimes with radio and TV \\
\hline Higher education & Entirely online \\
\hline
\end{tabular}

\section{LITERATURE REVIEW}

\section{COVID-19 and Distance Learning}

Different countries use different terms like 'flexible learning', 'open learning', and 'remote learning', and 'distance learning' which are alternative means to usual ways of teaching-learning process. For the matter of uniformity, this article uses 'distance learning' afterwards. Just like COVID-19 is first found in China, the strategy of 'School's out. But Class's ON' was started in China and later spread to the world to practice undisrupted learning (Zhou et al., 2020). Countries like Singapore have made early preparation of training teachers with expectation of closure of schools. Some countries like Lebanon have opted to send kids home with lessons as homework, promoting independent distance learning with the help of parents and peers (World Bank, 2020a).

As COVID-19 continues spreading in many countries of world, how to keep learning in disruption has become a major challenge to the global education community (Huang, et al., 2020). Using the China's strategy of 'School's Out, But Class On', UNESCO has designed a 'handbook on facilitating flexible learning'. UNESCO has designed a flexible learning approach which can offer choices in the educational environment, as well as customizing a given course to meet the needs of individual learners (Huang et al, 2020). The handbook has provided a comprehensive guide on how to use online teaching in a flexible manner. Though the handbook noted the limitations of Chinese experience of not addressing distance learning in areas with no internet connectivity TV cables, it did not address how the disrupted class can proceed in such disadvantaged situations.

Distance learning aims to make learners more self-determined and independent, while teachers became more as learning facilitators (Wiki, 2019). Learners can be offered choices based on their needs (e.g., study during evenings or weekends) (Huang et al., 2020). The location of learners to carry out learning activities and access learning materials can also be flexible anywhere at any time via mobile devices, such as at campus, home, public transport, airport or even on a plane (Collis et al., 1997; Gordon, 2014; McMeekin, 1998).

Different technologies like email and social networks can be used to conduct flexible learning. Online education as a subset of distance learning (which also includes TV, radio, and other means which do not require internet) has always been concerned with providing access to education experience that are at least more flexible in time and in space than campus based education (Huang et al., 2020). Online learning is defined as learning experiences in synchronous or asynchronous environments using different devices (e.g., mobile phones, laptops, etc.) with internet access. In these environments, students can be anywhere (independent) to learn and interact with instructors and other students (Singh \& Thurman, 2019). In online learning, learners can interact directly with the learning content that they find in multiple formats (e.g., video, audio, document, etc.). Additionally, they can also choose to have their own learning sequenced, directed, and evaluated with the assistance of a teacher (Huang et al., 2020).

Goole meet and zoom are important online means of teaching (Basilaia \& Kvavadze, 2020). The countries that are having the limited technologies have problems in schools are not ready for the complete implementation of the countrywide online education (Basilaia \& Kvavadze, 2020; Sintema J, 2020).

On April 2020, World Bank has provided guidance on distance learning; which is better inclusive compared to UNESCO handbook. The bank has provided different strategies of distance learning for different levels of education. Distance learning approach of World Bank has the 'aim to ensure all children and youth have access to a quality education' (World Bank, 2020b:1). Distance learning can ensure that students' continue learning through a variety of avenues.

From table, it is possible to understand that the bank has considered different means of learning depending on the levels of education. In other words, the appropriate means of learning at each level of education has been suggested by the bank. Hence, how to conduct learning at different levels in countries with poor internet connectivity and digital infrastructures like Ethiopia was not given high consideration. Moreover, the bank did not consider the infrastructural facilities to students at all levels are almost similar except graduate students who are mostly self-dependent and might have access to internet and capacity to buy laptops, desktops, and smart phones. However, in developing countries like Ethiopia, there are higher education students of first degree from rural areas where there is no internet access and even electricity.

Notwithstanding that UNESCO and World Bank has provided guidelines to proceed the disrupted class, there is uncertainty about when face-to-face classes, exams, assessment procedures and, of course, enrollments that are part of the cycle of any academic year can be resumed. At the moment, it is impossible to make predictions. However, as indicated in the study of IESALC (2020), most Spanish and Italian Universities are expected to open their doors in September 2020/21 academic calendar. 


\section{Distance Learning and Rural-Urban Divide}

In developing countries, education inequality is still widely observed between rural and urban areas. Income disparity, various institutional barriers, and different parenting styles, among others, are regarded as potential causes of education inequality (Zhang et al., 2015). Most parents in the rural areas do not take much interest in their children's schoolwork (Litheko, 2012).

There is 'digital divide' between rural and urban students to access to technology and opportunities to learn ICT skills. There are no hardware, software, the Internet and technology support within public schools. There is also difference on how frequently students and teachers use technology within the classroom (Wang, 2013).

The rural-urban infrastructure disparities indicate that urban areas can boast electricity and telecommunications capabilities, but rural areas remain unconnected and hence disadvantaged (Gulati, 2008). The lack of ready access to technology is a key barrier to technology integration for developing areas (Wang, 2013).

Both teachers and students in rural are disadvantageous in technological facilities, with regard to teachers, the study of Clark (2000) shows that urban teachers in the U.S. have positive reactions towards technology integration. The findings include three points: 1) urban teachers feel confident about their ability to use technology; 2) urban teachers believe that technology is an integral part of their classroom; and 3) urban teachers want more software and equipment in their classrooms. However, research indicates that rural schools do not have teachers with the same qualifications and confidence levels in technology integration as urban schools do. Lacking experienced and skilled teachers and technical training have been an ongoing problem for rural schools (Herselman, 2003).

With regard to students, as indicated in Wang (2013), students from rural schools score lower on all the Internet inequality indicators (digital access, autonomy of use, social support, Internet use and self-efficacy) and are therefore more disadvantaged in Internet usage status than their urban peers. Researchers have also argued that students in low-income areas often use computers for repetitive activities, whereas students in high-income areas often use technology for higher-order thinking, problem solving, and other intellectually challenging activities (Songer, Lee, \& Kam, 2002 in Wang, 2013).

\section{The Challenges of Online Learning}

In the handbook of UNESCO (2020) and World Bank (2000b) guideline, online teaching has given great focus particularly to secondary and higher education. Higher education institutions have chosen to continue offering regular courses using virtual platforms and always with the guarantee of credit transfer. Here, however, there is a huge difference between those HEls that have their own capacities both technological and in teaching resources and, above all, experienced teachers and those that do not (IESALC, 2020, p. 33).

In comparison, online teaching cannot achieve the face-to-face emotional communication between teachers and students, and lacks real-time feedback of information and classroom constraints (Cheng, 2020). Moreover, if the closure long lasts, achieving the objectives of course will be very difficult (IESALC, 2020).

As stated in World Bank (2020b), while digital technologies can offer a wide set of capabilities for distance learning, most education systems in low- and middle-income countries, including schools, children and/or teachers, lack access to high-speed broadband or digital devices needed to fully deploy online learning options. As such, education systems need to consider alternative ways for students to continue learning when they are not in school, like in the current COVID-19 crisis. Online libraries, TV broadcasts, guidelines, resources, video lectures, online channel are important alternatives of face-to-face learning (Basilaia \& Kvavadze, 2020; World Bank, 2020b).

As stated in Huang et al. (2020), several challenges were reported during the application of online learning in the global wide according to the literature and international experts. For example, (a) Internet connection can be unreliable if there are thousands of learners learning simultaneously; (b) Some instructors can find it difficult to find online resources that are the most suitable in their teaching contexts because thousands of resources are published online; (c) Several instructors and learners do not have the appropriate digital skills to teach and learn online. This can make the online teaching/learning experience inconvenient for them; (d) Several learners lack crucial learning competencies, such as adaptation, independent study, and self-regulation, which are key factors for successful online learning; and, (e) Several instructors simply use direct instructions without considering important features of online learning, such as interactivity, social presence, and cognitive presence, resulting in unmotivating learning experiences.

Radio education and Television education are important broadcast distance learning models (World Bank, 2020b). However; as analysed in the coming section, in countries like Ethiopia where the large number of people in live rural areas with no electricity, TV and radio programs might not be applicable.

\section{METHODOLOGY}

This article adopted a qualitative research methodology of situational analysis. Situational analysis (Clarke, 2005) is a research methodology that uses the situation broadly conceived as the unit of analysis. Clarke (2005) further stated that situational analysis can be used to produce a thick analysis of discourses, texts, "symbolisms of the nonhuman". As a research method, situational analysis is designed to (a) illustrate the complexities found within and surrounding social situations as they change, become stable, and create patterns and positions, (b) reveal subjugated knowledges' and marginalized perspectives, and (c) empirically decenter "the knowing subject" (Clarke, 2005). 
Situational analysis extends and goes beyond grounded theory (Clark et al., 2015). Unlike grounded theory which focuses on action, situational analysis focuses on the situation of inquiry broadly conceived; the ultimate unit of analysis, and understanding its elements and their relations (Whisker, 2018). Situational analysis constructs "the situation" empirically by making three unique ecological-relational maps: situational maps, social worlds/arenas maps, and positional maps (Clark, 2005).

This methodology helps me to integrate my personal and professional experiences related to the issue as an integral component of critical research design and continued analysis. In the situational mapping, the author considers human and nonhuman elements that shape effectiveness of distance learning during the pandemic. For example, availability internet connectivity, TV, and Radio, mobile phone and other digital devises are important nonhuman elements. While availability educated parents and other family members and teachers are important human elements of the situational map. The social world map helps to interpret the relation between students, parents, and teachers that helps effective continual of the disrupted school. The positional map helps to explain how different positions affect distance learning. Social stratification i.e. sex, child labour demands by parents, socioeconomic status (occupation, income, and educational attainment) are important elements in the positional map.

This article is based on a hypothesis: 'All students are equally benefited from distance learning during COVID-19'. In order to prove this hypothesis, the author had research questions of: do all students have equal access to internet, TV, and Radio? How the socioeconomic statuses of parents affect distance learning? What is the role of student-parent-teachers relation in the effectiveness of distance learning during the pandemic? In order to answer these questions, the author has considered different reports and literatures to contextualize and analyse the data. Besides, the author has gathered data using informal discussions, email, and phone call that helps me in making the situation analysis.

\section{ANALYSIS}

\section{Intersectionality and Educational Disadvantage of Rural Students}

Intersectionality considers different intersecting inequalities. Intersectionality posits that social divisions interrelate in terms of the production of social relations and in terms of people's lives. This term is used for the first time by Kimberle Crenshaw to mean overlapping categories of discrimination (Crenshaw, 1994). There are different specific criteria for social categorization i.e. sex difference, sexuality, ethnicity, race, age, height, educational achievements, appearance, and colour of eyes (Anthias, 2012). Social inequality, power, and politics have been primary concerns of intersectionality since its inception (Collins, 2012). Anthias (2012) further states that such differences are not fixed elements of social landscape. This requires social policies that can consider multiple inequalities.

Collins (2012, p. 446) comprehensively stated that 'social structures such as neighbourhoods, schools, jobs, religious institutions, recreational facilities, and physical and cyberspace marketplaces are the institutional expressions of social inequalities of race, class, gender, age, ethnicity, religion, sexuality, and ability'. Collins (2012) further stated that these different structures offer different opportunities and rewards. These different characteristics of people create different conditions of life. Using the term of Lohmann and Ferger (2014), with regard to education, the rural students suffer from absence of equality of conditions leads to 'educational poverty', and 'educational inequality' due to absence of equal opportunities.

Individuals from low-income families tend to invest less in education than those from high-income families (Botezat, 2016). From human development perspective, education is more than an instrument of development; it is a development by itself (Tilak, 2001). Rural areas are not just suffered from income poverty. What is revealing in rural Ethiopia is human poverty; people are denied of choices and opportunities for living a tolerable life (See: UNDP, 1992, p. 2). In this regard, World Bank (1994, p.2) also indicated that 'poverty is not only a problem of low incomes; rather it is a multi-dimensional problem that includes low access to opportunities for developing human capital and to education'. Using the notion of Amartia Sen, students in the rural areas lack capabilities; freedom that a person has in terms of choices and opportunities 'to lead lives they have reason to value' (Sen, 1999).

The school situation before the closure of schools due to COVID-19 is not the concern of this article though it might have an influence on the effectiveness of distance learning after the closure. Educational inequality for rural students is discussed on how different modes of distance learning i.e. online, TV, and Radio are applicable compared to urban students. The socioeconomic background of students and student-parent-school relations are also important conditions that create educational inequality particularly to rural students.

\section{Paradoxes of Distance Learning in Ethiopia}

While internet use is widespread in everyday life and work for many in high income countries, this is not the case in most lowand middle income countries (UNICEF, 2020b). As stated in IESALC (2020), from the seven continents, Africa is by far low in connectivity (17\%) followed by Latin America (47\%). Similarly, Internet World Stats (2020a) indicated that Africa has the least internet coverage; only $39.3 \%$ by far followed by Asia (53.6\%). This makes African students not to have access to connectivity when they return home. In Africa in general and Ethiopia in particular there are more mobile lines than connected homes.

Ethiopia is formally connected to the Internet in January 1997, with the ISP being the then Ethiopian Telecommunication Corporation, now ethio-telecom (Atnafu, 2014). Compared to the rate of developments for Internet access in the rest of the world, it is difficult to say that access to Internet and the Internet penetration in Ethiopia has developed well. As indicated in Internet World Stats (2013), despite Ethiopia constitutes $9 \%$ of the Africa's population, it accounts only to less than $1 \%$ of African Internet access. Internet World Stats (2020a) also indicated that it is only $17.8 \%$ of the Ethiopia's population who have access to internet service. 
As indicated in World Bank, (2019), while the coverage of grid electricity in urban areas of Ethiopia is $97 \%$, it is only $12 \%$ in rural areas In the report of OECED (2020), despite students are supposed to have smartphones than laptops, the case is worst in rural Ethiopia; where students lack smartphones too. The haves are curious about how to get fast internet connections where most students are connected. However, in poor countries like Ethiopia, students lack internet connections at all particularly in rural areas. In Ethiopia rural area refers to locality having less than 2000 inhabitants (CSA, 2007). Moreover, in this study rural area is characterized by occupation, where agriculture is a dominant sector; lack of electricity and internet connectivity.

By 2014 the internet penetration rate in Ethiopia was less than $2 \%$ the social networking statistics shows that Facebook penetration in Ethiopia is comparable to the country's Internet penetration rate despite it is low compared to Facebook penetration in some African countries, which is 34.63\% in Tunisia and 17.16\% in Egypt (Atinafu, 2014). Internet Society (2019) also reported that many people in developing countries still do not use a mobile phone. And when the unconnected do gain access, such access may not be of adequate quality or low enough cost to be meaningful to them.

Online teaching is performed at higher education institutions. For graduate students, reading materials, assignments, and home take exams are sent via emails. In some universities, defenses of Thesis and dissertation are made face-to-face with respect to the rules of the national state emergency due to COVID-19. In some other universities, defense is made using Zoom, and Google Meet. However, there are electric power and internet interruptions that affect effectiveness of this practice. In case of undergraduate students, despite the Ethiopian Ministry of Science and Higher Education (MOSHE) has planned to precede distance learning online, none of the universities are effective due to lack of internet access to the majority of students. Moreover, most undergraduate students do have email address to communicate.

As stated somewhere in the next sections, primary and secondary school students of private schools have better access to internet connectivity and ability to afford for digital devices. This is because, students of private schools have better socioeconomic background and these schools are located dominantly in major cities. Unlike public schools, private schools better distributed reading materials on applications of Telegram and whatsapp. Private schools also conducted home-take final exams which are distributed in hard copies and returned back a week after.

Moreover, the Ethiopian Ministry of Education designed online teaching to higher education which is not functioning effectively. Also, National Model Exams of Grade 8 and grade 12 model exams of 2020 academic year are reported to be conducted on Telegram. It is said that the question will stay online for few days to make it accessible to students with different accessibility challenges including power interruption. However, alternative mechanisms are not presented for rural areas that don't have access to internet as well as smart phone at all. This can create educational inequality and discrimination against the rural students.

In addition to the large inequities in access to the internet, TV and radio access varies considerably both across and within countries. In the context of Sub-Saharan Africa, TV and radio ownership rates among urban households were more than double that of rural households with the largest disparities appearing in sub-Saharan Africa (UNICEF, 2020b). UNICEF (2020b) further stated that Ethiopia is the lowest in Sub-Saharan Africa in which only $28 \%$ of the population have radio ownership. With this condition, it is obvious that rural students cannot be benefited from TV and radio programs as well. On 09 June 2020 UNICEF has made a report on how education is keep going during COVID-19 using TV and Radio platforms in Ethiopia. From the report some students who do have access to TV and educated parents have better advantage of perusing their study at home (Sewnet, 2020). However, the report does not clearly mention how students in rural areas spent their time during the pandemic.

\section{Family background and Children's Education}

Family background has a great impact on the performance of children's schooling. Among this difference, being the resident of rural area is the glimpse of other socioeconomic differences with the urban people.

Beyond, being children of rural family, poor family background of children creates multidimensional challenges to effectively perform education. Particularly during the time of COVID-19 where students are advised to stay and learn at home, students can't have access to reading materials such as text books, and other relevant infrastructures. As stated in Ayoroa et al. (2010), the poor don't send their children to school because they cannot scarify the financial support that these children provide through home labour. In Ethiopia, the study of ILO (2018) indicated that school attendance of children aged 7-14 is $82.4 \%$ in urban areas while $56.7 \%$ in rural areas. Therefore, it cannot be difficult to imagine that children of the rural poor who stayed at home due to COVID19 will be highly requested the labour. School closure disproportionately affect female students since they engaged in common household chores include babysitting, cleaning, cooking, shopping and caring for sick household members (ILO, 2018).

The poorer regions of the world, namely Sub-Saharan Africa, and South and West Asia experienced the lowest literacy rates (UNESCO, 2011). Financial security within the family plays a key role in how parents and their children make decisions about educational choices and provision which is related to the socioeconomic status of the family, which in turn is greatly influenced by the education level of parents (Drajea \& O'Sullivan, 2014, p. 149). Similarly, Nelson (2009) stated that parents who have not attended college, on the other hand, tend to have less direct knowledge of the economic and social benefits of a post-secondary education. Thus, some of these parents may prefer that their children to work rather than to attend college.

Christine Eden comprehensively stated that poverty, in terms of low family income affects children in several ways: the absence of learning habits and experiences at home; a lack of access to computers; lack of a sense of self-esteem through appropriate interactions with parents; poor housing; an unhealthy diet; possible mental health issues within the family; domestic violence; and the stress associated with low pay or unemployment (Eden, 2013, p. 35 Cited in Drajea and O'Sullivan, 2014). 


\section{Student-Parent-school relation and Distance Education}

During the time of COVID-19 strong school administration, parents, and teachers' support is important. However, in the context of Ethiopia, school administration and teachers supervision to students is different between public and private schools. Private schools are concentrated in urban areas. Urban schools have qualified teachers and attractive salaries compared to their counter parts of government schools in both rural and urban areas. Curriculum difference is found between private and urban schools rather than in specialty. Rural schools have poor facilities as well as poor school-parent relation. McCracken and Barcinas (1991) stated that urban schools were larger; had more teachers, administrators, and support staff; and offered more courses and extra-curricular activities. This is a great implication that there is weak support to rural students compared to students in urban areas.

From their study in China, Ayoroa and his colleagues stated that rural/urban education disparity is thus perpetuated as areas with lower quality education are provided with less-qualified teachers' (Ayoroa, et al., 2010). This is partly due to low salaries and few teaching and learning supplies for rural schools.

\section{COVID-19, Learning at home and Parents' Help to Children}

Families background i.e. occupation, level of education, and family size have significant impact on students educational attainment. This creates difference urban and rural areas. Most of the rural people in Ethiopia are agrarians who seek the labour of their children. Therefore, when schools are closed due to COVID-19, this is a good opportunity for rural parents to use the labour of students. Besides, unlike the urban parents, who mostly have behaviour of guiding their children to study, rural parents don't have such experience. Particularly female students will be engaged in household chores and will not be given time to study compared to their counterparts. Due to weak guidance culture of parents, the rural students to spend their time in plying than studying even in their free times.

It is not surprizing that children of educated family have an opportunity to get different support from their parents. Such parents can demonstrate positive attitude about education, monitor their children's videos, games, and internet use, encourage their children to read, help them in doing assignments and correcting them, and guide their children to be effective in their education career. The influence of family background on children's educational experiences has a curious place within the field of sociology of education (Lareau, 1987). The higher the social class, the higher the income, education, material possessions, and status (Evans \& Herr, 1978, p. 119-120).

Kotrlik and Harrison (1989) concluded that students perceive that their parents influence their career choice more than any other person, and the mother is more influential than the father. That is why urban students have better educational and occupational aspiration compared to rural students (McCracken \& Barcinas, 1991). Lareau (1987, p. 76) also stated that 'Many factors-e.g., parents' educational attainment, the amount of non-work time parents can invest in their children's schooling-affect the kind and degree of parental involvement'. Lareau further stated that parents' involvement in the education of their children is vital for their academic achievements.

Education capability of parents and information about schooling are determinant factors that shape parents participation in their children's schooling (Gooding, 2001; Lareau, 1987). Moreover, parents of rural students were less likely to expect their children to advance their education (McCracken \& Barcinas, 1991).

Education capability of parents determines their involvement and assistance to children's education. The less educational capability of the parent, the more the parents turn the responsibility for education to teachers'. In the middle-class community, parents had extensive information about classroom and school life (McCracken \& Barcinas, 1991). Similarly, Parental education is consists on different activities like the supervision of their children social settings, activities and friends (Rizwan et al., 2014).

It should also be noted that distance education requires more discipline and commitment on the part of the student, which perhaps explains why it is more successful among older people, that is, postgraduates, compared to undergraduates (IESALC, 2020). Students of rural areas who do have parents engaged in agricultural activities and peaty trading require labour of the students than helping them to study their subjects.

'The face-to-face experience is particularly important for vulnerable students who have often had fewer opportunities for interaction in areas such as that offered by a university campus that allows them to strengthen their social skills, so that, if the closure is prolonged, they will be more disadvantaged than other students' (IESALC, 2020, p. 16).

\section{COVID-19 and the Situation of Distance Learning in Ethiopia}

Following the school closures and the response plan set by the Ministry of Education, the respective regional education bureaus have initiated the continuity of education using various media, including using educational radio programmes and television learning programmes provided by the Ministry of Education. In addition, some private schools, mostly in urban areas, have been focusing on engaging parents and their students in learning through a Telegram mobile application, which is more widely used in Ethiopia (Hailu, 2020; Tiruneh, 2020).

However, the Ethiopian Ministry of Education has taken strategies that homogenises students. The Ministry suggested Radio and TV programs for primary education, TV education program to secondary education, and online teaching to higher education. These strategies would benefit only the advantaged students from urban areas and do have educated family background. Others who are the majority live in rural areas and cannot be benefited from all suggested strategies. Even, these distance learning strategies are not provided effectively. 
As stated in Tiruneh (2020), radio and television lessons may work for some children in urban areas. However, the Ministry as well as regional education bureaus do not have clear evidence on how many parents in rural areas have access to radios and satellite television. Given that more than $80 \%$ of the Ethiopian population lives in the rural areas with limited or no access to electricity, it is least likely that radio and television lessons would reach all primary and secondary school children in the rural areas. Even when radio and television lessons reach some of the rural children, it is unlikely that those children get sufficient support from their parents at home because their parents have never been to school. This makes the existing strategies very limited that do not consider the existing situation of the majority students who are exposed to multiple inequalities. For sure, this can perpetuate educational inequality between the urban advantaged and the rural disadvantaged students.

As a default, the Ethiopian Ministry of Education has been encouraging schools and parents to help all children continue to learn from home through remote learning. However, there are limited mechanisms in place to ensure that ALL children can continue to learn at home. As indicated in Cordry and Wilson (2005), educational researchers argue that parental involvement in the education of their children at home is equally important. Despite it is impossible to say that the unschooled rural parents do not help their children at all (Ejaz, 2009), the nature of families work, and the norm of coaching their schooling is different between schooled and unschooled parents (Lareau, 1987). Trineh (2020) also stated that home-schooling is particularly challenging in lowincome countries like Ethiopia because many parents have not themselves been to school and there is a lack of the necessary infrastructure to support remote learning.

In most private schools of Ethiopia which are concentrated to the cities of capital of the country and regional states i.e. Addis Ababa, Bahir Dar, Hawassa, Adama, and Mekele, students have better advantage of learning at home via Telegram. The schools provide different worksheets to students and perform better compared to students of public schools. Some private schools also provide home take exams. Here, it is good to mention that students of private schools have better family background at least in terms of income, and education. As stated by Tiruneh (2020), there are no efforts by the public schools in urban and rural areas to keep their students learning from home. It is understandable that most of the public school teachers and parents have limited or no access to Internet connectivity, but most importantly the teachers lack the preparedness to work in such unprecedented circumstances. Therefore, though the focus of this article is on rural students who are the majority, the urban poor students also in a disadvantaged position. However, the rural students are the most disadvantaged whom multiple inequalities intersect.

The problem of distance learning is not limited to primary and secondary education. Higher education programs for undergraduate, graduate, and post graduate students are not also clearly functioning. Masters and PhD students who are doing their Thesis and dissertations are communicating with advisors on emails. The ministry of education also directed that graduation will be made to these students. However, there is no clear direction and also functioning to other students. From my data gathered some universities share materials to students (particularly to Masters) via email. Despite this, there is no clear direction how students will be assessed and how long such uneven practices will stay.

\section{CONCLUSION}

Due to COVID-19, face-to-face learning has been disrupted. It is also impossible to predict when the normal face-face-learning will be resumed (IESALC, 2020). This makes the China's model of 'School is Out, But Class's On' to be conducted effectively. However, the Ethiopian government failed to make interventions to support the marginalized rural students of any level of education. Particularly the rural students who do have family background of little or no schooling are at great disadvantaged position. Hence, considering different dimension and devising means to make student active learners is vital.

In rural areas where there is no internet and electricity, the existing government intervention is not functioning to the majority rural students. Despite distribution is the challenge, printed materials to students to study at home are important (World Bank, 2020b). However, in case of Ethiopia, since there was no any preparation before the closure of schools, institutions were not ready to provide reading materials to their students before they go home. There is also no monitoring from schools and local governments in Ethiopia that, how distance learning is functioning by addressing the diverse needs of children with multiple inequality. Beyond, rural character of students, there are many primary and secondary school children in Ethiopia with special educational needs, who may not benefit equally from the radio and television lessons.

The cultural experiences in the home facilitate children's adjustment to school and academic achievement, thereby transforming cultural resources into what he calls cultural capital (Bourdieu 1977a, 1977b cited in Lareau, 1987). Students in rural areas are more or less homogeneous which limits their opportunity to share experience unlike urban students (McCracken \& Barcinas, 1991). This makes information gap between the access haves and the have-nots regarding different government decisions. Hence, as indicated in World Bank (2020b) and IESALC (2020), long-time closure of schools might lead to drop out of students which worst rural students' educational inequality.

\section{POLICY IMPLICATION}

At the time of COVID-19, students are encouraged to stay at home and read there. This is great challenge to students of the rural society. Because; for rural children, school is everything; it is a place to learn, to study, and to have fun. Once they return home, there is no a comfortable environment to study. As indicated in Nelson (2014), children of parents who did not pursue higher education are less likely to have frequent observational learning opportunities to develop dedicated study habits. Hence, rural students have not a model to look around or they don't have someone to coach them to study. Therefore, government 
organizations, non-governmental organizations, and other concerned bodies should consider the existing realities of students and devising mechanisms to reach them. Particularly, the rural parents have to be oriented to encourage their children to study at home. A temporary arrangement should be made for students in rural areas to receive reading materials and read it.

As indicated in World Bank (2020b), there is digital technology access difference among students. Hence, policymakers have to consider equity concerns; as the most vulnerable students are most probably affected disproportionately hard and most likely lack the ability to access digital resources. Beyond developing new content, it would be better to focus on curating existing (especially free, 'open') content and aligning it to the curriculum.

In addition, government guidelines should clearly state how students can be evaluated. As noted above, despite intermittently given, there are some practices of teaching on TV, radio, and online. But it is not clear direction how to evaluate them properly. Therefore, how and when students should be tested or alternate assessment requirements should be set properly. This will give students a better focus on their learning.

\section{LIMITATION}

Due to the state of emergency of COVID-19, the author did not make a rigorous research method. Both quantitative and qualitative aspects were not addressed well. How students and their parents feel about children education is not well considered from parents as well as students perspective. Lack of theoretical and empirical literatures on educational situation during COVID19 in Ethiopia limits this article.

Focusing on rural-urban divide does not mean that all urban students are better-off than rural students in a complete manner. So, this article is limited in showing such complexes found between urban-rural settings, and among rural as well as urban settings themselves. However, through its relational understanding, the article can serve as a nice glimpse how socioeconomic difference create educational disadvantage between students during the periods of pandemic. It also depicts how rural students are in a more disadvantage position due to multiple inequalities compared to urban students in a relative speaking. Therefore, the author recommends a further comprehensive study in Ethiopia how distance learning modalities were practiced in urban and rural areas by incorporating the view of schools, students, and parents using a rigorous research method.

\section{REFERENCES}

Anthias, F. (2012). Intersectional what? Social divisions, intersectionality and levels of analysis. Ethnicities, 13(1), 3-19. https://doi.org/10.1177/1468796812463547

Atnafu, S. (2014). Local Internet Content: The Case of Ethiopia. In 12th Globelics International Conference, Addis Ababa, Ethiopia.

Ayoroa, P., Bailey, B., Crossen, A., \& Geo-JaJa, M. A. (2010). Education in China: the urban/rural disparity explained. In: J.Zajda (eds.), Globalisation, ideology and education policy reforms (pp. 89-113). Springer, Dordrecht. https://doi.org/10.1007/978-90481-3524-0_7

Basilaia, G., \& Kvavadze, D. (2020). Transition to online education in schools during a SARS-CoV-2 coronavirus (COVID-19) pandemic in Georgia. Pedagogical Research, 5(4), 1-9. https://doi.org/10.29333/pr/7937

Botezat, A. (2016). Educational poverty. The Gh. Zane Institute for Economic and Social Research of the Romanian Academy, lasi Branch

Cheng, X. (2020). Challenges of "School's Out, But Class's On” to School Education: Practical Exploration of Chinese Schools during the COVID-19 Pandemic. Sci Insigt Edu Front, 5(2), 501-516. https://doi.org/10.15354/sief.20.ar043

Clark, K. D. (2000). Urban middle school teachers' use of instructional technology. Journal of Research on Computing in Education, 33(2), 178-193. https://doi.org/10.1080/08886504.2000.10782308

Clarke, A. E. (2005). Situational analysis: Grounded theory after the postmodern turn. Thousand Oaks, CA: SAGE. https://doi.org/10.4135/9781412985833

Clarke, A. E., Friese, C., \& Washburn, R. (Eds.). (2015). Situational analysis in practice: Mapping research with grounded theory (Vol. 1). Left Coast Press. https://doi.org/10.4324/9781315420134

Collins, P. H. (2012). Social Inequality, Power, and Politics: Intersectionality and American Pragmatism in Dialogue. The Journal of Speculative Philosophy, 26(2), 442-457. https://doi.org/10.5325/jspecphil.26.2.0442

Collis, B., Moonen, J., \& Vingerhoets, J. (1997). Flexibility as a Key Construct in European Training: Experiences from the TeleScopia Project. British Journal of Educational Technology, 28, 199-217. https://doi.org/10.1111/1467-8535.00026

Cordry, S., \& Wilson, J. D. (2004). Parents as First Teacher. Education, 125(1), 56-62.

Crenshaw, K. (1994). Mapping the margins: intersectionality, identity politics and violence against women of color. In: M. A. Fineman \& R. Mykitiuk (Eds.), The Public Nature of Private Violence (pp. 93-118). New York: Routledge.

CSA (2007). Population and Housing Census of Ethiopia. Administrative Report.

Dorn, E., Hancock, B., Sarakatsannis, J., \& Viruleg, E. (2020). COVID-19 and student learning in the United States: The hurt could last a lifetime. McKinsey \& Company. 
Drajea, A. J., \& O'Sullivan, C. (2014). Influence of parental education and family income on children's education in rural Uganda, Global Education Review, 1(3), 149-166.

Ejaz, M. (2009). Contribution of Unschooled Parents in the Education of their Children: An Analysis. Pakistan Journal of Social Sciences (PJSS), 29(2).

Fu, T. M. (2005). Unequal primary education opportunities in rural and urban China. China Perspectives, 2005(60). https://doi.org/10.4000/chinaperspectives.500

Gooding, Y. (2001). The relationship between parental educational level and academic success of college freshmen.

Gordon, N. A. (2014). Flexible Pedagogies: technology-enhanced learning. In The Higher Education Academy. https://doi.org/10.13140/2.1.2052.5760

Gulati, S. (2008). Technology-enhanced learning in developing nations: a review. International Review of Research in Open and Distance Learning, 9(1), 1-16. https://doi.org/10.19173/irrodl.v9i1.477

Hailu, B. H. (2020). Education Response to COVID-19: How Can Basic Education Be Implemented in Ethiopia? Retrieved from https://riseprogramme.org/blog/COVID-19-ETH-Basic-Education

He, F., Deng, Y., \& Weina, L. (2020). Coronavirus disease 2019: What we know? Journal of Medical Virololy, $2020,1-7$. https://doi.org/10.1002/jmv.25766

Herselman, M. E. (2003). ICT in Rural Areas in South Africa: Various Case Studies. Proceedings of Informing Science, June 2003, $945-$ 955. https://doi.org/10.28945/2680

Huang, R. H., Liu, D. J., Tlili, A., Yang, J. F., Wang, H. H., et al. (2020). Handbook on Facilitating Flexible Learning During Educational Disruption: The Chinese Experience in Maintaining Undisrupted Learning in COVID-19 Outbreak. Beijing: Smart Learning Institute of Beijing Normal University.

IESALC (2020). COVID-19 and higher education: Today and tomorrow. Impact analysis, policy responses and recommendation.

ILO (2018). Ethiopia National Child Labour Survey. Ethiopia National Child Labour Survey 2015 / International Labour Office, Fundamental Principles and Rights at Work Branch (FUNDAMENTALS); Central Statistical Agency (CSA). - Addis Ababa: ILO, 2.

Internet Society (2019). Internet Society Global Internet Report: Consolidation in the internet economy.

Internet World Statistics (2013). Usage and Population Statistics. Retrieved from http://www.internetworldstats.com/stats1.htm

Internet World Statistics (2020a). Usage and Population Statistics. Retrieved from https://www.internetworldstats.com/stats1.htm

Internet World Statistics (2020b). Internet Usage Statistics. World Internet Users and 2020 Population Stats. Retrieved from https://www.internetworldstats.com/stats.htm

Lareau, A. (1987). Social class differences in family-school relationships: The importance of cultural capital. Sociology of education, 73-85. https://doi.org/10.2307/2112583

Litheko, S. R. S. (2012). The difference in performance between schools situated in the urban areas and those in the rural areas of Lesotho. Electronic Journal for Inclusive Education, 2(9), 2.

Lohmann, H., \& Ferger , F. (2014). Educational Poverty in a Comparative Perspective: Theoretical and Empirical Implications. SFB 882 Working Paper Series, No. 26.

McCracken, J. D., \& Barcinas, J. D. T. (1991). Differences between rural and urban schools, student characteristics, and student aspirations in Ohio. Journal of Research in Rural Education, 7(2), 29-40.

McMeekin, A. (1998). Flexible Learning and Teaching and IT. Keynote address to the 1998 Monash University Flexible Learning and Technology Conference, 1 October 1998.

Ministry of Education of the People's Republic of China. (2020). Notice on Several Issues concerning Targeted Teacher Work during the Pandemic Prevention and Control. 2020-02-10. Retrieved from http://www.moe.gov.cn

Nelson, J. K. (2009). Impact of Parent Education on Student Success. Online Submission.

Rizwan, M., Adeel-Ur-Rehman, Shabbir, S. W., \& Warriach, I. A. (2014). Explorative Study of Parents Education Effect on the Socialization of their Children (A Case of District Muzaffar Garh). Research on Humanities and Social Sciences, 4(26), 81-86.

Sandholtz, J. H., Ringstaff, C., \& Dwyer, D. C. (1992). Teaching in high-tech environment: Classroom management revisited. Journal of educational computing research, 8. https://doi.org/10.2190/Y5NE-V9RQ-FD63-WC2N

Sen, A. K. (1999). Development as Freedom. New Delhi: Oxford University Press.

Sewnet, Z. (2020). In Ethiopia: Keeping children learning during COVID-19. UNICEF, Addis Ababa, Ethiopia. Available at: https://www.unicef.org/ethiopia/stories/ethiopia-keeping-children-learning-during-covid-19

Singh, V., \& Thurman, A. (2019). How Many Ways Can We Define Online Learning? A Systematic Literature Review of Definitions of Online Learning (1988-2018). American Journal of Distance Education, 33(4), 289306. https://doi.org/10.1080/08923647.2019.1663082

Sintema, E. J. (2020). Effect of COVID-19 on the Performance of Grade 12 Students: Implications for STEM Education. Eurasia Journal of Mathematics, Science and Technology Education, 16(7), em1851. https://doi.org/10.29333/ejmste/7893

Tilak, J. B. G. (2001). Household Expenditure on Education in India: A Few Stylized Facts. In S. M. Dev, P. Antony, V. Gayathri and R.P. Mamgain (Eds.), Social and Economic Security in India (pp.191-218), New Delhi: Institute for Human Development. 
Tiruneh, D. T. (2020). COVID-19 School Closures May Further Widen the Inequality Gaps between the Advantaged and the Disadvantaged in Ethiopia. Retrieved from https://www.riseprogramme.org/blog/COVID-19_ethiopia_school_closures

UNDP (1997). Human Development Report, New York: Oxford University Press.

UNI CEF (2020a). Ethiopia COVID-19. Situational Report No. 5, 11-16 April 2020.

UNICEF (2020b). Promising practices for equitable remote learning Emerging lessons from COVID-19 education responses in 127 countries. Innocent Research Brief.

Whisker, C. (2018). Review: Adele E. Clarke, Carrie Friese \& Rachel S. Washburn (2018). Situational Analysis: Grounded Theory After the Interpretive Turn (2nd ed.). Forum Qualitative Sozialforschung / Forum: Qualitative Social Research, 19(3), Art. 35. https://doi.org/10.17169/fqs-19.3.3138

Wiki. (2019). Open learning. Retrieved from https://en.wikipedia.org/wiki/Open_learning.

Wise, T., Zbozinek, T., Michelini, G., Hagan, C. C., \& Mobbs, D. (2020). Changes in risk perception and protective behavior during the first week of the COVID-19 pandemic in the United States. https://doi.org/10.31234/osf.io/dz428

World Bank (1994). Poverty Reduction in South Asia. Washington DC.

World Bank (2019). International Bank for Reconstruction and Development. 2019-Tracking SDG7-The Energy Progress Report. Retrieved from https://trackingsdg7.esmap.org/data/files/download-documents/2019-Tracking\%20SDG7-Full\%20Report.pdf

World Bank (2020a). Guidance Note on Education Systems' Response to COVID19. 25 March 2020. Retrieved from http://pubdocs.worldbank.org/en/450881585235950757/COVID19-Education-Sector-Guidance-Note-March26.pdf

World Bank (2020b). The World Bank Education Global Practice Guidance Note: Remote Learning \& COVID-19. Updated April 7, 2020.

Zhang, D., Li, X., \& Xue, J. (2015). Education inequality between rural and urban areas of the People's Republic of China, migrants' children education, and some implications. Asian Development Review, 32(1), 196-224. https://doi.org/10.1162/ADEV_a_00042

Zhou, L., Li, F., Wu, S., \& Zhou M. (2020). "School's Out, But Class's On”, The largest online education in the world today: Taking China's practical exploration during the COVID-19 epidemic prevention and control as an example. Best Evid Chin Edu, 4(2), 501-519. https://doi.org/10.15354/bece.20.ar023 